\title{
A VERSENGÉS, GYŐZELEM ÉS VESZTÉS SZUBJEKTÍV JELENTÉSE MAGYAR, KÍNAI ÉS MAGYARORSZÁGON TANULÓ KÍNAI DIÁKOK KÖRÉBEN
}

\author{
SEBESTYÉN NÓRA ${ }^{1}$ - FÜLÖP MÁRTA ${ }^{1,2}$ \\ ${ }^{1}$ MTA TTK Kognitív Idegtudományi és Pszichológiai Intézet \\ ${ }^{2}$ ELTE Pszichológia Doktori Iskola \\ E-mail: sebestyen.nora@ttk.mta.hu; fulop.marta@ttk.mta.hu \\ Beérkezett: 2014. október 10. - Elfogadva: 2014. december 20.
}

\begin{abstract}
Az utóbbi évtizedben növekszik azoknak a kutatásoknak a száma, amelyek a versengés és kimenetei, a győzelem és a vesztés, kulturális meghatározottságát vizsgálják (például FüLÖP, 2013; WATKINS, 2006), azonban nem tudunk olyan kutatásról, amely bevándorlók konceptualizációját tárta volna fel.

Jelen kutatás célja a kinai, magyar és Magyarországon élő kinai diákok versengéssel, gyózelemmel és vesztéssel kapcsolatos szubjektív jelentésének feltárása, továbbá az akkulturáció nézetrendszerre gyakorolt hatásának vizsgálata volt.

A vizsgálatban 166 (52 kinai, 60 magyar és 54 Magyarországon élo" kínai) 13-15 éves diák vett részt. Annak érdekében, hogy a kulturális kitettség hatása megbizhatóan vizsgálhatóvá váljon, a migráns mintát a Magyarországon tartózkodás ideje alapján két részre osztottunk. A szubjektív jelentések feltáráshoz az Asszociatív Csoport Analizis (AGA, SZALAY és BRENT, 1967) technikát alkalmaztuk, melynek keretében a diákok a versengés, gyözelem és vesztés hívószavakra asszociáltak (1 perc/hívószó). A jelentéskomponensek és egymáshoz viszonyított százalékos arányuk az asszociációk súlyozása és kategorizálása révén rajzolódott $k i$.

Az eredmények az akkulturációs folyamatok szubjektív jelentésre gyakorolt hatására hívják fel a figyelmet. A migráns minta jelentésstruktúrája több komponenssel kapcsolatban hasonlóságot mutatott a magyar mintáéval. Az egyes komponensek különbözö mértékben voltak érzékenyek az akkulturációra, a legérzékenyebb elem az érzelmi aspektus volt. A kulturális kitettség hatása leginkább a vesztés fogalommal kapcsolatban érvényesült: a régebb óta Magyarországon tartózkodó diákok jelentésstruktúrája a magyarra, a rövidebb ideje hazánkban tartózkodó migránsoké a kínaira hasonlít.
\end{abstract}

Kulcsszavak: AGA, versengés, gyözelem, vesztés, kínai migránsok, kultúrközi összehasonlító vizsgálat 


\section{BEVEZETÉS}

Bár a versengés és kimenetelei, a győzelem és vesztés kulturális meglapozottságával kapcsolatban az utóbbi időben felélénkültek a kutatások (FÜLÖP, 2013; WATKINS, 2006), ez idáig nem született olyan vizsgálat, amely bevándorlók versengés-, győzelem- és vesztésértelmezését kísérelte volna meg feltárni. A tanulmányban először a versengés kínai és magyar kulturális kontextusát ismertetjük, kitérve a kínai migránsok helyzetére is, majd a versengés és kimenetei, a győzelem és vesztés szubjektív jelentését feltáró vizsgálatunkat mutatjuk be.

\section{Versengés, gyözelem és vesztés Kínában}

Annak ellenére, hogy Kína gazdasága és oktatási rendszere is erősen versengés központú, a versengés nem vált ki ellenérzést az érintettekből. WATKINS (2006, 2007) vizsgálatai kimutatták, hogy a versengés nem viseli meg a kínai és hongkongi diákokat, természetesnek veszik, sőt az amerikaiakkal, angolokkal, és magyarokkal összevetve, legpozitívabban a hongkongi középiskolások viszonyulnak hozzá. FÜLÖP Márta (2013) a versengés szubjektív jelentését vizsgálta hat ország (kínai, magyar, angol, török, japán, indiai) egyetemistái között, és azt találta, hogy a versengés motivációs aspektusa a kínai mintában volt a leghangsúlyosabb. A hallgatók mellett a kínai tanárok is pozitívan állnak a versengéshez, kiemelik annak motivációs, önfejlesztő aspektusát (CHEN, 2014). A versengés pozitívabb képét, motivációs jellegét magyarázza továbbá, hogy a versengés nem destruktív interperszonális kontextusban történik. Kelet-ázsiai kontextusban a versengés az interperszonális harmónia elvével együtt érvényesül, így nem befolyásolja negatív irányba a versenytársak kapcsolatát (FÜLÖP, 2009, 2013). Az egyéni jó teljesítmény nem kerül negatív megítélés alá, hanem a fejlődés szintjét kijelölő kollektív motivációs tényező mások számára is, ami intenzív erőfeszítéssel, kellő kitartással bárki számára elérhető lesz (LI, 2012). A kínai sikerdiskurzus tehát az erőfeszítésen és kitartáson keresztüli célelérést hangsúlyozza. Az erőfeszítésetika a kínai kudarcfelfogásban is érvényesül, a hibázás a társadalmi elvárásoknak való megfelelés hajtóereje és a személyes növekedés alapja (LI, 2012).

\section{Versengés, gyözelem és vesztés Magyarország}

A magyar állampolgárokat ambivalens viszony füzi a versengéshez; egyrészt elismerik társadalmi szükségességét, azonban megvalósulását kritikával illetik, jellemzően negatívan viszonyulnak hozzá (FÜLÖP, 2001). A negatív versengésképet részben magyarázza, hogy a társadalmi szinten jelentkező anómia (például TóTH, 2009) a versengéssel kapcsolatban is megmutatkozik, a versengés tipikusan immorális, agresszív eszközökhöz kötődik Magyarországon (például FüLÖP, 2001, 2013; OROSZ, 2009). A versengéssel kapcsolatos negatív szemlélet pedig stabilnak mutatkozik korcsoportok, foglalkozáscsoportok és területek (gazdaság, oktatás) 
mentén is (FÜlÖP, 2013; FÜLÖP, ROLAND-LEVY és BERKICS, 2004). FÜLÖP (2013) a korábban említett, a versengés szubjektív jelentését feltáró, hat kultúrát összehasonlító vizsgálatában azt találta, hogy a magyar egyetemisták versengésfogalma volt a leginkább érzelemtelített, dominánsan negatív érzelmekhez, agresszióhoz és konfliktushoz kapcsolódott. A magyar versengésfelfogás a negatív érzelmi töltet mellett erősen eredményorientált, a versengés jellemzően a győzelemhez társul (FülÖP, 2013, SÁNDOR, Orosz és FülÖP, 2010; FülÖP és BERKICS, 2003). Az eredményorientáció azonban egy immoralitást toleráló és ellenséges interperszonális közegben zajlik, ami a versengés motivációs aspektusának destruktív irányt szabhat (FülÖP, 2013). Az ellenséges keretben a sikeres tanuló nem a csodálat és elismerés tárgya lesz, és követendő szerepmodellé válik a kínai gyakorlathoz hasonlóan, hanem társas ellenérzést vált ki és pejoratív címkét kap (például KozÉKI és HRABAL, 1983). A magyar sikerfelfogás továbbá nem meritokratikus alapokra épül, a sikerhez nem a kiemelkedő képességeken és belső erőforrásokon (például kitartás, szorgalom) keresztül vezet az út, a pozitív kimenet a megfelelő kapcsolatokhoz, valamint agresszív, immorális eszközökhöz kötődik (SZABÓ, 2012). A kudarcdiskurzus sem erőfeszítés alapú, hanem erősen pesszimista és negatív érzelmi színezetű (FÜLÖP és BERKICS, 2003; FÜLÖP, 2013). A pedagógusok és a szülők nem alakítanak ki megfelelő megküzdési stratégiákat a vesztéssel kapcsolatban a gyermekekben, sokszor ők maguk sem tudják konstruktívan kezelni a negatív kimenetet (FÜLÖP, 2013; SÁNDOR, 2010). A társadalmi-történeti narratíva pedig az áldozati, vesztes, kiszolgáltatott szerepet erősíti (például LÁSzLÓ és FÜLÖP, 2011; KovÁcs és PÁNTYA, 2012).

\section{Kinai migránsok}

A globalizáció és a migrációs folyamatok hatására egyre növekszik azon személyeknek a száma, akik átmenetileg vagy tartósan hazájuktól eltérő kultúrákban élnek (Berry, PoOrtinga, Segall és DAsen, 2002). A kultúrát váltó személyek akkulturáción mennek keresztül, amely jelenség a közvetlen és folyamatos kulturális találkozások hatására létrejövő viselkedéses, érzelmi és kognitív változásokat takarja (például BERRY és mtsai, 2002; MASGORET-WARD, 2006). Az akkulturáció erősen érzelemtelített folyamat, amelyet tipikusan két dimenzió - az eredeti kultúra értékeinek, normáinak megőrzése, valamint az új kultúra értékeinek, normáinak átvétele - mentén vizsgálnak (BERRY és mtsai, 2002).

A kínai migránsok leginkább a szülői elvárások, nevelési stílus és továbbtanulási aspiráció kapcsán kerültek az akkulturációs vizsgálatok középpontjába. Az eredmények (MIN-TZU LIAO, 2007; LEE és ZHOU, 2014) alapján úgy tűnik, hogy a kínai kultúrának vannak olyan mélyen beépült „teljesítménybarát” kulturális elemei (például a tanulás konfuciánus értéke, sikernarratíva), amelyek stabil és inherens részét képezik a kínai identitásnak, és aktuális tartózkodási helytől függetlenül meghatározzák az attitűdöt. Továbbá a konstans elemek mellett a változó környezetre érzékenyebb komponensek is találhatók a kínai nézetrendszerben (például oktatási gyakorlat, MiN-TzU LiAO, 2007). 
A kínai migránsok magyarországi iskolai tapasztalataival kevés kutatás foglalkozott (például NGUYEN LUU és munkatársai, 2009). NYíRI és FEISCHMidT (2007) migráns gyermekekkel folytatott vizsgálatában a megkérdezett kínai diákok többsége a magyar és kínai oktatási rendszer különbségéről számolt be: a család egységes álláspontját képviselve a magyar iskolákat kevésbé tartották erősnek, tapasztalataik alapján a kínai iskolákat nagyobb fegyelem, magasabb követelmények és erősebb verseny jellemzi. A magyar oktatási rendszer sajátossága mellett hat azonban a kínai családi háttér intenzív teljesítményigénye is, a kínai migráns szülők egységesen a tanulmányi versenyben való helytállásra szocializálnak (NYíRI és FEISCHMIDT, 2007).

\section{A KUTATÁS ISMERTETÉSE}

\section{A kutatás célja}

A fentiekből látható, hogy a kínai migráns gyermekek Magyarországon a versengéssel és eredményhez való hozzáállással kapcsolatban eltérő üzenetekkel szembesülnek. Felmerül tehát a kérdés, hogy milyen versengésfogalmak konstruálódnak a bevándorló diákok körében az eltérő elvárások hatására. Ez idáig egy olyan vizsgálatról tudunk, amely kimutatta az akkulturáció hatását a versengéssel kapcsolatos viselkedésben. AKkermans, HaRzing és WitTeloOstujin (2010) eredményei alapján azok a holland diákok, akik több mint 3 hónapot töltöttek angolszász kultúrában, és angol nyelven vettek részt a kísérletben, kevesebb együttmüködő választást adtak a Fogoly Dilemma játékban, mint azok a diákok, akik nem rendelkeztek ilyen kulturális tapasztalattal.

AKKERMANS és munkatársai (2010) vizsgálatán kívül jelenleg nem tudunk olyan kutatásról, amely a migrációs folyamatok versengésre gyakorolt hatását vizsgálná, továbbá amely a viselkedésnél mélyebb réteget érintő konceptualizációt (versengésfogalmat) tárná fel az akkulturációban érintett összes szereplő bevonásával (célország, anyaország, migráns csoport).

A jelen kutatás célja a kínai, magyar és Magyarországon élő kínai diákok versengéshez, győzelemhez és vesztéshez kapcsolódó szubjektív jelentésének feltárása, valamint az akkulturáció jelentésrendszerre gyakorolt hatásának vizsgálata.

\section{A kutatás módszere}

A vizsgálatban a SzALAY és BRENT (1967) által Amerikában kidolgozott Associative Group Analysis (AGA, Asszociatív Csoport Analízis) technikát alkalmaztuk, mely az egy perc alatt adott asszociációk súlyozása és kategorizálása révén tárja fel a vizsgált fogalom szubjektív jelentésének fő dimenzióit.

A módszer gyakran alkalmazott technika kutúrközi kutatásokban (például SZALAY és BRYSON, 1977; SZALAY, STROHL, Fu és LAO, 1994), valamint olyan longitudinális vizsgálatok során, amelyben a fogalomstruktúra időbeni alakulásának 
feltárása a cél (Kelly, 1985). Az akkulturációs folyamatok szintén a (kulturális) tanulás lehetőségét rejtik, ezáltal feltételezhető a kulturális kitettség következtében bekövetkező fogalomstruktúra-átalakulás. Az asszociációs módszer segítségével feltárhatóvá válik, hogy az akkulturálódó csoport milyen mértékben és milyen életterületeken adaptálódik a befogadó ország nézetrendszeréhez (például SzALAY és BRYSON, 1977).

\section{Minta}

A vizsgálatban 52 kínai (21 fiú, 31 lány; átlag életkor: 13,9), 60 magyar (20 fiú, 40 lány; átlag életkor: 13,6) és 54 Magyarországon élő kínai (28 fiú, 27 lány; átlag életkor: 14,8) 13-15 éves diák vett részt. A kínai és magyar adatfelvételel két-két fővárosi iskolában történt, Pekingben és Budapesten. A budapesti kínai mintába kerülésnek az volt a kritériuma, hogy a gyermek 13-15 éves legyen és kínai szülókkel rendelkezzen. A Magyarországon tanuló kínaiak csoportja átlagosan 7,2 éve tartózkodott hazánkban. Annak érdekében, hogy a kulturális kitettség hatását megbízhatóan vizsgálhassuk, a bevándorló kínai mintát két részre osztottuk: megkülönböztettük az 5 évnél kevesebb ideje (átlag: 3,3 év) és a több mint 6 éve Magyarországon élő kínai gyermekek csoportját (átlag: 11,7 év). Zatykó és munkatársai (ZATYKó, SCHUMANN és BALOGI, 2013) hivatalos statisztikák és kutatási jelentések, valamint önálló kérdőíves kutatásuk eredményei alapján a Budapesten felső tagozaton tanuló kínai diákok száma megközelítőleg 100-150 fő, így a vizsgálatunkban szereplő 52 kínai migráns diák jól reprezentálja az adott csoportot.

\section{Az eljárás részletes menete}

\section{Adatgyüjtés}

Az AGA adatgyűjtési protokollját követve a diákoknak egy perc állt rendelkezésére a hívószóval kapcsolatban asszociálni (SzALAY és BRENT, 1967). Vizsgálatunkban a diákoktól összesen hét tanuláshoz és versengéshez kapcsolódó hívószóra kértünk asszociációkat. Az eljárás menete minden országban kötött volt, az adatok három alkalommal lettek felvéve tanóra elején csoportos helyzetben, alkalmanként 2/2/3 hívószóra kérdezve. A hívószavak sorrendje minden országban azonos volt: tanulás, versengés, vesztés, iskola, gyözelem, tanár és erófeszítés. A magyar hívószavak kínai megfelelőinek kiválasztásában két magyarul és kínaiul is anyanyelvi szinten beszélő kolléga vett részt. Az instrukciót a diákok saját anyanyelvükön olvashatták, Pekingben mandarin kínaiul, Budapesten magyarul. A Magyarországon tanuló kínai diákok esetében az instrukció kétnyelvű volt, mandarinul és magyarul is szerepelt a papíron, a diákok dönthették el, hogy milyen nyelven válaszolnak. A kínai válaszok magyarra fordítását két magyarul és kínai nyelven is folyékonyan beszélő személy végezte, akik közül az egyik kínai, a másik magyar nemzetiségű volt. Az adatok végső elemzése magyar nyelven történt. 


\section{Adatelemzés}

Az AGA technika adatelemzését követve első lépésként az egyedi válaszokat súlyoztuk aszerint, hogy az asszociációs sorrendben hol találhatók. Az AGA technika szerzői a konkrét súlypontokat egy vizsgálatukra alapozták (SZALAY és DEESE, 1978), az eredmények azt mutatták, hogy az egyhetes késleltetéssel megismételt asszociációs feladat során az első asszociációs feladatban elsőként adott szavak második alkalommal is nagyobb valószínúséggel váltódtak ki korábban. A teszt-reteszt módszer alapján figyelembe vett rangstabilitás időbeli alakulása mentén az AGA technika súlyozása a következőképpen alakul:

$$
\begin{aligned}
& \text { 1. asszociáció }=6 \text { súlypont } \\
& \text { 2. asszociáció }=5 \text { súlypont } \\
& \text { 3. asszociáció }=4 \text { súlypontot, } \\
& \text { 4., 5., 6., 7. asszociáció }=3-3-3-3 \text { súlypont } \\
& \text { 8., 9. asszociáció }=2-2 \text { súlypont } \\
& \text { 10., 11., 12. asszociációtól }=1-1-1 \text { súlypont }
\end{aligned}
$$

Az elemzés következő lépéseként a szemantikailag egy csoportba tartózó asszociációkat kategorizáltuk, melyet két független kódoló végzett. A kódolók közötti reliabilitás 0,8 és 0,9 között mozgott. Az egyet nem értést a kódolók megbeszélés útján oldották fel, a vitás pontoknál az eredeti nyelv és eredeti asszociációsor, valamint egy kínai nyelvű kollégával való konzultáció döntött.

Jelen tanulmányban a versengés, győzelem és vesztés hívószavakkal kapcsolatos eredményeket ismertetjük.

\section{EREDMÉNYEK}

Az eredményekkel kapcsolatban megvizsgáltuk a válaszadás nyelvét is, azonban mivel az öt évnél kevesebb ideje hazánkban tartózkodó diákok 90\%-a kínaiul, a hat évnél régebb óta Magyarországon tartózkodó diákok 92\%-a pedig magyar nyelven adott asszociációkat, ezért a válaszadás nyelve alapján nem végeztünk külön csoportbontást. A továbbiakban a Magyarországon tartózkodás ideje mentén címkézzük a részmintákat. A következőkben az egyes hívószavak mentén mutatjuk be az eredményeket.

\section{Versengés}

Az asszociációk tartalomelemzése során 11 közös, mindhárom mintában jelentkező kategória alakult ki: Eredmény; Negatív érzelem, állapot; Pozitív érzelem, állapot; Sport; Oktatás; Szórakozás; Személyek; Szinonima; Motiváció; Képesség; és Egyéb kategória. A 11 kategória teljesen lefedte a magyar és a migráns minta versengésfogalmát. A kínai minta esetében 4 további kategória emelkedett ki: a versengés területére vonatkozó Gazdaság és Munka, az igazságossággal kapcsola- 
tos kifejezéseket (például igazságos, szabályszegés) takaró Moralitás, valamint az együttműködés és egységre vonatkozó szavakat tartalmazó Kooperáció.

Annak érdekében, hogy a minták összehasonlíthatóvá váljanak, a közös kategóriák relatív súlyait vetettük statisztikai elemzés alá. A páronkénti összehasonlításhoz Fisher-egzakt próbát alkalmaztunk. A közös kategóriákat bemutató 1. táblázatban folytonos vonal jelzi a szignifikáns különbéget az egymás melletti minták között, szaggatott vonal mutatja a szignifikáns különbséget a nem egymás melletti minták között, és a vonal hiánya a szignifikáns különbség hiányára utal.

1. táblázat. A súlyozott kategóriák mintánkénti összevetése a versengéssel kapcsolatban

\begin{tabular}{|c|c|c|c|c|c|}
\hline \multirow{2}{*}{ Kategóriák } & \multicolumn{4}{|c|}{ G y a korisági sorrend } & \multirow{2}{*}{$\begin{array}{l}\text { Fisher- } \\
\text { próba }\end{array}$} \\
\hline & 1. & 2. & 3. & 4. & \\
\hline \multicolumn{6}{|c|}{ EREDMÉNYORIENTÁCIÓ } \\
\hline ÖSSZ & $\mathrm{M}(27 \%)$ & 6 év< $(20 \%)$ & 5 év > $(20 \%)$ & $\mathrm{K}(15 \%)$ & $p<0,001$ \\
\hline GYÖZELEM & $\mathrm{M}(22 \%)$ & 5 év $>(15 \%)$ & 6 év $<(12 \%)$ & K $(9 \%)$ & $p<0,001$ \\
\hline VESZTÉS & M $(5 \%)$ & $\mathrm{K}(3 \%)$ & 6 év $<(3 \%)$ & 5 év> $>(2 \%)$ & $p<0,001$ \\
\hline \multicolumn{6}{|l|}{ ÉRZELEM } \\
\hline ÖSSZ & $\mathrm{M}(23 \%)$ & 6 év < $(22 \%)$ & 5 év> $>(10 \%)$ & $\mathrm{K} \quad(3 \%)$ & $p<0,001$ \\
\hline NEGATÍV & $\mathrm{M}(19 \%)$ & 6 év< $(19 \%)$ & 5 év $>\quad(9 \%)$ & $\mathrm{K} \quad(2 \%)$ & $p<0,001$ \\
\hline Konfliktus & $\mathrm{M}(13 \%)$ & 5 év> $(8,5 \%)$ & 6 év $<\quad(6 \%)$ & $\mathrm{K}(0,1 \%)$ & $p<0,001$ \\
\hline Negatív érzelem & 6 év $<(13 \%)$ & $\mathrm{M}(6 \%)$ & $\mathrm{K}(1,9 \%)$ & 5 év $>(0,5 \%)$ & $p<0,001$ \\
\hline POZITÍV & M $(4 \%)$ & 6 év< $<(3 \%)$ & 5 év> $(1 \%)$ & $\mathrm{K}(1 \%)$ & $\begin{array}{c}\mathrm{M}-\mathrm{K}, \\
\mathrm{M}-5 \text { év }> \\
p<0,001\end{array}$ \\
\hline \multicolumn{6}{|l|}{ TERÜLET } \\
\hline ÖSSZ & 5 év $>(46 \%)$ & $\mathrm{K}(36 \%)$ & 6 év $<(28 \%)$ & $\mathrm{M}(19 \%)$ & $p<0,001$ \\
\hline SPORT & 5 év $>(31 \%)$ & $\mathrm{M}(15 \%)$ & 6 év< $<(13 \%)$ & $\mathrm{K} \quad(4 \%)$ & $p<0,001$ \\
\hline OKTATÁS & $\mathrm{K}(15 \%)$ & 6 év< $(9 \%)$ & 5 év $>\quad(8 \%)$ & M (1\%) & $p<0,001$ \\
\hline SZÓRAKOZÁS & 5 év> $(7 \%)$ & 6 év< $<(6 \%)$ & $\mathrm{M}(3 \%)$ & $\mathrm{K} \quad(1 \%)$ & $p<0,001$ \\
\hline SZEMÉLYEK & $\mathrm{K}(9 \%)$ & 5 év> $>(5 \%)$ & M $(4 \%)$ & 6 év $<\quad(2 \%)$ & $p<0,001$ \\
\hline Barát & 5 év $>(2 \%)$ & $\mathrm{K}(1,5 \%)$ & M $(0 \%)$ & 6 év $<\quad(0 \%)$ & $p<0,001$ \\
\hline MOTIVÁCIÓ & 6 év $<(16 \%)$ & $\mathrm{M}(14 \%)$ & $\mathrm{K}(14 \%)$ & 5 év $>(12 \%)$ & n.sz. \\
\hline SZINONIMA & $\mathrm{M}(10 \%)$ & 6 év< $(9 \%)$ & K $(8 \%)$ & 5 év> & n.sz. \\
\hline
\end{tabular}

Jelmagyarázat: $\mathrm{M}=$ magyar, $\mathrm{K}=$ kínai, 6 év $<=6$ évnél régebb óta Magyarországon tartózkodó, 5 év $>=5$ évnél kevesebb ideje Magyarországon tartózkodó

Az eredményorientáció általánosan és külön-külön a győzelem és vesztés is a magyar minta esetében a leghangsúlyosabb. A leginkább eredményorientált, a versengést annak két végpontja, a győzelem és vesztés mentén szemlélő jelentésrendszer a 
magyar diákok esetében mutatkozott. A kínai diákok versengésfogalmát határozta meg legkevésbé az eredmény. A migráns gyerekek versengésfogalma közepes mértékben eredmény- és győzelemorientált, szignifikáns különbség mutatkozott mind a magyar, mind a kínai mintától $(p<0,001)$. Vesztés esetében nem találtunk szignifikáns különbséget a kínai és kínai migráns minták között. Nem találtunk szignifikáns különbséget a migráns mintában a Magyarországon tartózkodás ideje mentén.

Az érzelmekhez kapcsolódó kifejezések relatív súlya a magyar és a 6 év < migráns mintában volt a legnagyobb, szignifikáns különbség mutatkozott a többi mintához képest $(p<0,001)$. Az érzelmi vonatkozás tekintetében különbséget találtunk a migráns mintában a Magyarországon tartózkodás ideje mentén: azok a kínai migránsok, akik régebb óta élnek hazánkban szignifikánsabban negatívabb versengésfelfogással rendelkeznek, mint a rövidebb ideje hazánkban tartózkodók, versengésfelfogásuk az érzelmi mintázat tekintetében a magyarokéhoz közelít. Ha azonban az alskálákat is figyelembe vesszük, láthatóvá válik a különbség: a magyarok esetében a versengés konfliktusos aspektusa a leghangsúlyosabb, míg a 7 évnél régebb óta hazánkban tartózkodó kínaiak esetében az általános negatív érzések dominálnak. A legkevesebb érzelem a kínaiak jelentésrendszerében található.

A területek összesített súlya az 5 év $>$ migráns diákok esetében volt a legjelentősebb, őket a kínaiak, majd a 6 év< migránsok követték, legkevésbé a magyar mintában volt a területeknek jelentésformáló ereje. A speciális területek kapcsán a sport az 5 év> migránsok számára, az oktatás a kínai mintában, a szórakozás pedig a migráns mintában volt a legjelentősebb $(p<0,001)$.

A versengés személyközi hátterét tekintve a kínai minta versengésfogalmában a legjelentősebb az interperszonális aspektus. A hazánkban eltöltött időnek szintén jelentősége van az 5 év> migránsok jelentésstruktúrájában szignifikánsan nagyobb súllyal szerepel a személyek kategória, mint a 6 év < migráns diákok esetében $(p<0,001)$. Valamint esetükben a kínaiakhoz hasonlóan azonosítható volt a barátság alkategória, szemben a 6 év < migráns kínaiakkal és a magyarokkal.

A motiváció és szinonima kategóriája mentén nem találtunk szignifikáns különbséget a minták között.

\section{Gyözelem}

A győzelem kapcsán összesen 9 közös, mindhárom mintában azonosítható kategória jelent meg: Pozitív érzelmek, Negatív érzelmek, Szinonima, Vesztés, Verseny, Terület, az eredményre, teljesítményre és jutalomra vonatkozó Eredményorientáció, a győzelem hátterében álló belső és külső okokat tartalmazó Attribúció, valamint az Egyéb kategória. A közös kategóriák teljes egészében lefedik a magyar győzelemfogalom jelentésstruktúráját. A kínai és a Magyarországon tanuló kínaiak esetében további közös kategória a győzelem interperszonális hátterét adó Személyek kategória. Az együttműködéshez és egységhez kapcsolódó Kooperáció és az erkölcshöz kapcsolódó Moralitás kategóriája kizárólag a kínai mintában volt azonosítható. A közös kategóriák mintánkénti összevetése a 2. táblázatban látható. 
2. táblázat. A súlyozott kategóriák mintánkénti összevetése a győzelemmel kapcsolatban

\begin{tabular}{|c|c|c|c|c|c|}
\hline \multirow{2}{*}{ Kategóriák } & \multicolumn{4}{|c|}{ Gyakorisági sorrend } & \multirow{2}{*}{$\begin{array}{c}\text { Fisher- } \\
\text { próba }\end{array}$} \\
\hline & 1. & 2. & 3. & 4. & \\
\hline \multicolumn{6}{|l|}{ ÉRZELEM } \\
\hline ÖSSZ & M $(32 \%)$ & 6 év $<(24 \%)$ & 5 év $>(22 \%)$ & $\mathrm{K}(13 \%)$ & $p<0,001$ \\
\hline POZITÍV & $\mathrm{M}(\mathbf{2 6 \%})$ & 6 év< $(20 \%)$ & 5 év> $(17 \%)$ & K $(8 \%)$ & $p<0,0001$ \\
\hline NEGATÍV & M $(6 \%)$ & 5 év> $(6 \%)$ & 6 év $<(4 \%)$ & K $(4 \%)$ & n.sz. \\
\hline \multicolumn{6}{|l|}{ TERÜLET } \\
\hline ÖSSZ & $\mathrm{K}(26 \%)$ & 6 év $<(18 \%)$ & 5 év $>(18 \%)$ & $\mathrm{M}(5 \%)$ & $p<0,0001$ \\
\hline SPORT & K $(7 \%)$ & 5 év $>\quad(6 \%)$ & 6 év $<(6 \%)$ & $\mathrm{M}(5 \%)$ & n.sz. \\
\hline \multicolumn{6}{|c|}{ EREDMÉNYORIENTÁCIÓ } \\
\hline ÖSSZ & 6 év $<(22 \%)$ & $\mathrm{M}(20 \%)$ & 5 év $>(13 \%)$ & $\mathrm{K}(10 \%)$ & $p<0,0001$ \\
\hline Materiális jutalom & $\mathrm{M}(14 \%)$ & 6 év $<(13,5 \%)$ & $\mathrm{K}(4,5 \%)$ & 5 év $>(4,3 \%)$ & $p<0,0001$ \\
\hline \multicolumn{6}{|c|}{ GYÖZELEM-VESZTÉS } \\
\hline $\begin{array}{l}\text { SZINONIMA- } \\
\text { GYŐZELEM }\end{array}$ & $\mathrm{M}(17 \%)$ & 6 év $<(11 \%)$ & 5 év $>(10 \%)$ & $\mathrm{K}(9 \%)$ & $p=0,0014$ \\
\hline VESZTÉS & $\mathrm{K}(8 \%)$ & $\mathrm{M}(4 \%)$ & 7 év $<(1 \%)$ & 5 év> (1\%) & $p<0,0001$ \\
\hline ATTRIBÚCIÓ & $\mathrm{M}(12 \%)$ & 6 év $<(12 \%)$ & $\mathrm{K}(11 \%)$ & 5 év $>(10 \%)$ & n.sz. \\
\hline VERSENY & 7 év $<(10 \%)$ & 5 év $>(10 \%)$ & M $(9 \%)$ & $\mathrm{K}(5 \%)$ & $p<0,0001$ \\
\hline
\end{tabular}

Jelmagyarázat: $\mathrm{M}=$ magyar, $\mathrm{K}=$ kínai, 6 év $<=6$ évnél régebb óta Magyarországon tartózkodó, 5 év $>=5$ évnél kevesebb ideje Magyarországon tartózkodó

Az érzelmi aspektus tekintetében a győzelem a magyar diákok számára a leginkább, a kínaiak számára a legkevésbé érzelemtelített fogalom, a migráns minta a kettő között található $(p<0,001)$. Mindegyik mintában a pozitív érzelmek dominálnak. A negatív érzelmek kapcsán nem találtunk szignifikáns különbséget a minták között.

A területekre vonatkozó kifejezések összességében a kínai és a kínai migráns mintában fedtek szignifikánsan nagyobb részt a jelentésből $(p<0,0001)$. Az eredmény magyarázható a differenciáltabb győzelemfelfogással, hiszen a kínai és migráns mintákban a mindhárom mintában jelentkező sport és versenyen kívül további 5 győzelemterület is azonosítható volt: oktatás, szórakozás, társadalom, háború, és élet. A mindhárom mintában azonosítható sport kategóriájával kapcsolatban nem találtunk szignifikáns különbséget a minták között.

Eredményorientáció tekintetében egyértelmü hatása van a hazánkban tartózkodás idejének: a 6 év< kínai migráns diákok esetében, a magyar mintához hasonlóan, az eredményorientáció szignifikánsan hangsúlyosabb $(p<0,0001)$, mint az 5 év> migráns diákok esetében, akik a kínai mintával mutatnak hasonlóságot. Az eredményorientáció növekedése, főleg a materiális jutalom jelentőségének növekedésével magyarázható.

A gyözelemhez kapcsolódó kifejezések a magyar mintában képezik szignifikánsan 
hangsúlyosabb részét a jelentésnek $(p=0,0014)$, a kínai és migráns minták között nem volt szignifikáns eltérés. A vesztés a kínaiaknál a leghangsúlyosabb, a magyar és a bevándorló minták között nem találtunk szignifikáns különbséget.

Az attribúciós kategória mentén nem találtunk szignifikáns különbséget a minták között.

A verseny kategóriája a magyar és a migráns diákok esetében a győzelem jelentésének szignifikánsan nagyobb részét magyarázta, mint a kínai mintában $(p<0,0001)$.

\section{Vesztés}

A vesztéssel kapcsolatban 11 közös, mindhárom mintában azonosítható kategória jött létre: a Negatív érzelmek, Pozitív érzelmek, Szinonima, Győzelem, Attribúció, Terület, Verseny és Egyéb kategóriák mellett azonosítottuk még a szociális közeg pozitív (például támogatás) és negatív (például lenézés) reakcióját tartalmazó Társas reakció, a megküzdés passzív és érzelemközpontú formáira vonatkozó Passzív Megküzdés (például beletörődés, pihenés) és aktív, problémaközpontú formáira utaló Aktív Megküzdés (például további küzdelem, önvizsgálat) kategóriáit is. A kínai és a migráns mintában további két közös kategória volt azonosítható: a vesztésben rejlő növekedési potenciált hangsúlyozó Fejlődés kategória (például tapasztalat, fejlődés) és a vesztés interperszonális vonását leíró Személyek kategória.

A közös kategóriák mintánkénti összevetése a 3. táblázatban látható.

$\mathrm{Az}$ érzelmek leghangsúlyosabban a magyar mintában jelentkeztek, akiket a 6 év < migránsok, majd az 5 év> migránsok, végül a kínaiak követtek. Az érzelmek terén a különbség a negatív érzelmek súlyával magyarázható, amellyel kapcsolatban szignifikáns különbség mutatkozott a minták között $(p<0,001)$, a pozitív érzelmek esetében nem találtunk szignifikáns különbséget.

A vesztésfogalom területi aspektusa a 6 év $<$ migránsok esetében volt a legjelentősebb, melyet a kínaiak, majd az 5 év $>$ migránsok követtek, legkevésbé a magyarok esetében volt hangsúlyos $(p<0,001)$. Speciális területek kapcsán az oktatás a kínaiaknál, a szórakozás 6 év< migránsok esetében volt a legjelentősebb terület. A sport a magyar és migráns mintában volt hangsúlyosabb.

A vesztéssel kapcsolatban adott szinonimák a magyar mintában szignifikánsan nagyobb súllyal jelentkeztek, mint a kínai és migráns mintákban $(p<0,0001)$. A gyözelemhez kapcsolódó kifejezések az 5 év> migránsok esetében a kínai mintához hasonlóan szignifikánsan nagyobb súllyal szerepeltek, mint a magyarok esetében $(p<0,001)$, a 6 év $<$ migránsok nem adtak győzelemmel kapcsolatos asszociációt. A vesztés és a győzelem aránya a kínaiaknál és a rövidebb ideje hazánkban tartózkodóak esetében volt a legkisebb a győzelem javára (6:8, 5:7), és a magyaroknál volt a legnagyobb a vesztés javára (16:3).

A megküzdéssel kapcsolatban szintén érvényesült a Magyarországon eltöltött idő hatása. Az összesített megküzdés szignifikánsan nagyobb súllyal képviseltette magát a kínaiak és az 5 év $>$ migránsok vesztésfogalmában $(p<0,001)$. Ez a mintázat az aktív megküzdés esetében is érvényesül $(p<0,001)$, a passzív megküzdéssel kapcsolatban nem találtunk szignifikáns különbséget a kínai migráns minták között. 
3. táblázat. A súlyozott kategóriák mintánkénti összevetése a vesztéssel kapcsolatban

\begin{tabular}{|c|c|c|c|c|c|}
\hline \multirow{2}{*}{ Kategóriák } & \multicolumn{4}{|c|}{ Gyakorisági sorrend } & \multirow{2}{*}{$\begin{array}{l}\text { Fisher- } \\
\text { próba }\end{array}$} \\
\hline & 1. & 2 & 3. & 4. & \\
\hline \multicolumn{6}{|l|}{ ÉRZELEM } \\
\hline ÖSSZ & $\mathrm{M}(52 \%)$ & 6 év< $<(42 \%)$ & 5 év> $(30 \%)$ & $\mathrm{K}(21 \%)$ & $p<0,001$ \\
\hline NEGATÍV & $\mathrm{M}(51 \%)$ & 6 év< $(40 \%)$ & 5 év> $(28 \%)$ & $\mathrm{K}(20 \%)$ & $p<0,001$ \\
\hline POZITÍV & 5 év $>(2 \%)$ & 6 év $<(2 \%)$ & $\mathrm{M}(1 \%)$ & $\mathrm{K}(1 \%)$ & n.sz. \\
\hline \multicolumn{6}{|l|}{ TERÜLET } \\
\hline ÖSSZ & 6 év $<(27,5 \%)$ & $\mathrm{K}(21 \%)$ & 5 év $>(17,5 \%)$ & $\mathrm{M}(7 \%)$ & $p<0,001$ \\
\hline OKTATÁS & $\mathrm{K}(10 \%)$ & 5 év> $(5 \%)$ & 6 év $<(3 \%)$ & $\mathrm{M}(1 \%)$ & $\begin{array}{l}\mathrm{K}-5 \text { év }> \\
p<0,001 \\
\mathrm{M}-6 \text { év }< \\
p<0,01\end{array}$ \\
\hline SZÓRAKOZÁS & 6 év $<(9 \%)$ & $\mathrm{M}(3 \%)$ & 5 év $>(1 \%)$ & $\mathrm{K}(1 \%)$ & $p<0,001$ \\
\hline SPORT & 6 év< $<(6 \%)$ & 5 év> $(3 \%)$ & $\mathrm{M}(3 \%)$ & $\mathrm{K}(1 \%)$ & $p<0,001$ \\
\hline \multicolumn{6}{|c|}{ GYŐZELEM-VESZTÉS } \\
\hline $\begin{array}{l}\text { SZINONIMA- } \\
\text { VESZTÉS }\end{array}$ & $\mathrm{M}(16 \%)$ & $\mathrm{K}(6 \%)$ & 5 év $>(5 \%)$ & 6 év $<(5 \%)$ & $p<0,0001$ \\
\hline GYŐZELEM & K $(8 \%)$ & 5 év> $>(7 \%)$ & $\mathrm{M}(3 \%)$ & 6 év< $<(0 \%)$ & $p<0,001$ \\
\hline \multicolumn{6}{|l|}{ MEGKÜZDÉS } \\
\hline ÖSSZ & $\mathrm{K}(17 \%)$ & 5 év > $(17 \%)$ & M (9\%) & 6 év< $<(5 \%)$ & $p<0,001$ \\
\hline AKTÍV & 5 év > (15\%) & $\mathrm{K}(13 \%)$ & $\mathrm{M}(5 \%)$ & 6 év $<(4,5 \%)$ & $p<0,001$ \\
\hline PASSZÍV & $\mathrm{K}(4 \%)$ & $\mathrm{M}(4 \%)$ & 5 év > $(2 \%)$ & 6 év $<(0,5 \%)$ & $p<0,01$ \\
\hline $\begin{array}{l}\text { TÁRSAS } \\
\text { REAKCIÓ }\end{array}$ & $\mathrm{K}(7 \%)$ & M (5\%) & 5 év> $(3 \%)$ & 6 év $<(3 \%)$ & $p<0,01$ \\
\hline VERSENY & $\mathrm{K}(7 \%)$ & 6 év< $(7 \%)$ & M (6\%) & 5 év> $(3 \%)$ & n.sz. \\
\hline ATTRIBÚCIÓ & 5 év> $(5 \%)$ & 6 év $<(3,5 \%)$ & $\mathrm{K}(2 \%)$ & $\mathrm{M}(1 \%)$ & $p<0,01$ \\
\hline
\end{tabular}

Jelmagyarázat: $\mathrm{M}=$ magyar, $\mathrm{K}=$ kínai, 6 év $<=6$ évnél régebb óta Magyarországon tartózkodó, 5 év $>=5$ évnél kevesebb ideje Magyarországon tartózkodó

A társas reakcióval kapcsolatos kifejezések szignifikánsan kisebb súllyal szerepeltek a kínai migráns mintában, mint a kínai mintában, valamint a régebb óta hazánkban tartózkodó kínaiak mintája szignifikánsan különbözött a magyarokétól is $(p<0,01)$.

A versennyel kapcsolatban nem találtunk szignifikáns különbséget.

Az attribúcióval kapcsolatos jelentésszegmentum hangsúlya mindegyik mintában alacsony volt, a migráns mintában szignifikánsan nagyobb súllyal szerepelt, mint a magyar mintában $(p<0,01)$. 


\section{DISZKUSSZIÓ}

Jelen kutatás fókuszában 13-15 éves kínai, magyar és kínai migráns diákok versengéshez és annak kimeneteihez, a győzelemhez és vesztéshez kapcsolódó szubjektív jelentésének feltárása, valamint az akkulturáció jelentésre gyakorolt hatásának vizsgálata állt.

A versengés, győzelem és vesztés szubjektív jelentésének mintán belüli összevetése lehetőséget biztosított a fogalomalkotás kultúraspecifikus mintázatainak feltárására.

Az eredmények alapján a kínai jelentésalkotás leíró és pragmatikus jellegủ az érzelmek meghatározó szerepe nélkül. Amennyiben az érzelmek mégis szerepet játszanak (lásd vesztés), akkor is azonosítható egy világos forgatókönyv, amely a célt és a motivációs tendenciákat helyezi előtérbe; a negatív érzelmek tehát nem befolyásolják negatív irányba a megküzdési potenciált. FÜLÖP Márta (2013) kínai és magyar középiskolások vesztéssel és győzelemmel kapcsolatos reakcióit vizsgálta és azt találta, hogy a kínaiak esetében az érzelmi és viselkedéses reakciók kevésbé mutattak egyértelmű együttjárást, mint a magyarok esetében.

A magyar konceptualizációra a kínaival szemben az érzelemfókuszú fogalomalkotás jellemző, a jelentés nagy arányban kapcsolódik az érzelmekhez. A magyar társadalom affektív fókuszát több vizsgálat is megerősíti (például FÜLÖP és BERKICS, 2003; LÁsZLÓ és FÜLÖP, 2011), a magyarok intenzív érzelemmel reagálnak a győzelemre és vesztésre, az érzelmi és viselkedéses reakciók között pedig szoros együttjárás van. FÜLÖP (2013) vizsgálatában a magyar középiskolások esetében a kínaiakkal szemben az érzelmek és a viselkedés jól értelmezhető összefüggésben voltak, így a magyarok esetében az érzelmek és a viselkedés egymástól nem függetlenek, hanem oksági kapcsolat tételezhető fel közöttük. Az erőfeszítést és stratégikus gondolkodást hangsúlyozó társadalmi forgatókönyv híján az egyéni tapasztalatoknak és érzelmeknek lesz meghatározó szerepe a viselkedés irányításában.

$\mathrm{Az}$ akkulturáció hatása mindhárom fogalommal kapcsolatban érvényesült. A versengés fogalommal kapcsolatban a régebb óta Magyarországon tartózkodó kínaiak versengés fogalmában a magyarokhoz hasonlóan a negatív érzelmek meghatározóbbak. A magyarokkal ellentétben azonban a fogalom nem konfliktushoz kapcsolódik, hanem az általános negatív érzelmek aránya hangsúlyosabb. Ez az eredmény utalhat arra, hogy a negatív érzelmek tekintetében nem a magyar minta átvétele dominál, hanem a migrációs folyamat hatása érvényesül, és a kultúraváltás eredményeként az új kultúrába való beilleszkedés nehézségei látják el negatívabb érzelmi színezettel a versengés jelentését (például BERRY és mtsai, 2002). Jelen vizsgálat további eredménye, hogy a versengés a rövidebb ideje hazánkban tartózkodó diákok esetében kötődik hangsúlyosabban a sport területéhez, ami magyarázható azzal, hogy ezen a területen érvényesülnek legkevésbé a nyelvi korlátok, ezért a társas összehasonlításnak egy migrációs helyzettől (nyelvi kompetenciától) független terepe lehet. A győzelem fogalom kapcsán a kínai migráns minta jelentésrendszere a magyarokéhoz hasonlóan eredményorientált, érzelemtelített és versenyhez kötődik. A hazánkban tartózkodás ideje mentén pedig a materiális jutalom jelentősége idővel növekszik, míg a személyes aspektus 
hangsúlya csökken. Mindegyik kínai migráns minta esetében az egzisztenciális jólét is jelentős szempont, ami a migráns státusz egzisztenciális bizonytalanságával magyarázható (FONG, 2011). A kínai migráns minta vesztésfogalma a hazánkban tartózkodás ideje mentén jelentős eltérést mutat: a rövidebb ideje hazánkban tartózkodó diákok vesztés fogalma a kínai mintával, míg a régebb óta hazánkban élő migránsoké a magyar mintával mutat hasonlóságot. Mindegyik migráns részmintára jellemző azonban a vesztés fejlődést szolgáló aspektusának megjelenése (a kínai mintához hasonlóan), amely a kínai kultúrának a kudarcból való profitáló szemléletét közvetíti (LI, 2012), valamint az Élet területének relatív hangsúlya, ami szintén magyarázható a migráns léttel járó nagyfokú bizonytalansággal (FONG, 2011).

A jelentéskomponensek nem egyforma mértékben voltak érzékenyek az akkulturációra, a legérzékenyebb komponensnek az érzelmi aspektus bizonyult. A migráns minták fogalmai érzelemtelítettebbek voltak. Az eredmény részben magyarázható a migrációs folyamatokat kísért kulturális sokkal (BERRY és mtsai 2002), a migráns lét érzelmileg instabilabbá teheti a kultúrát váltó egyéneket. A migráns pozícióval járó egzisztenciális bizonytalanság az összes fogalom esetében megmutatkozott. A bevándorló diákok érzelemgazdag fogalomalkotásában valószínűsíthetően a tartózkodási ország hatása is érvényesül, hiszen a magyar konceptualizáció egyik jellemzője az érzelemfókuszú fogalomalkotás. A migráns mintára jellemző eredményorientáltság és a materiális jutalomra való érzékenység (győzelem esetében) szintén a magyar hatással lehet magyarázható.

A vizsgált fogalmakkal kapcsolatban az akkulturációra a vesztés fogalom volt a legérzékenyebb, a kulturális kitettség idői hatása itt érvényesül egyértelműen: idővel a kínaiakra jellemző negatív információból profitáló megközelítés, a vesztés konstruktív felfogása eltűnik, a jelentés a magyar konceptualizációhoz közelít. Más vizsgálatok szintén kimutatták, hogy olyan stabilabbnak hitt konstruktumok, mint a személyiségdimenziók és az önértékelés, migráns minták esetében a kulturális kitettség hatására a befogadóországra jellemző irányba változnak (GÜNGÖR, Bornstein, de Leersnyder, Cote, Ceulemans és Mesquita, 2012; Heine és LEHMAN, 2004). Azonban fontos megjegyezni, hogy a régebb óta Magyarországon tartózkodó gyermekek jellemzően magyarul válaszoltak, ezért a nyelv is közvetítheti a vesztéshez való kevésbé konstruktív hozzáállást. A nyelv a kulturális keretváltás triggereként működhet, és beindíthat az adott kultúrára jellemző válaszadást (például Kemmelmeier és Cheng 2004; Akkermans és mtsai, 2010). AKKERMANS és munkatársai (2010) korábban említett vizsgálatában a kísérletben angol nyelven részt vevő holland diákok esetében mutattak ki versengőbb, az angolszász kultúrára jellemző viselkedést. Bikulturális személyek esetében a kulturális keretváltás gazdagon dokumentált jelenség a szakirodalomban (BENETMARTINEZ és mtsai, 2006). Jelen kutatási dizájn azonban nem volt alkalmas arra, hogy eldöntsük, hogy idővel a migráns gyermekek konceptualizációja ténylegesen megváltozik a tartózkodási országra jellemző irányban, vagy kulturális gazdagodás történik, és fennmarad mindkét kultúrára jellemző fogalomalkotás, amit a gyermekek nyelvhasználattól függően képesek váltogatni. Ennek eldöntésére a nyelvet független változónak tekintő, szisztematikusan manipuláló további vizsgálatok szükségesek. 


\section{IRODALOM}

Akkermans, D., Harzing, A., W., \& Witteloostujin, A. (2010). Cultural accommodation and language priming. Management International Review, 50(5), 559-583.

Benet-Martínez, V., Lee, F., \& Leu, J. (2006). Biculturalism and cognitive complexity: Expertise in cultural representations. Journal of Cross-Cultural Psychology, 37(4), 386-407.

Berry, J. W., Poortinga, Y. H., Segall, M. H., \& Dasen, P. R. (2002). Cross-cultural psychology: Research and applications. Cambridge: Cambridge University Press.

Chen, K. (2014). What American educators can learn from Chinese secondary education. American Secondary Education, 42(2), 69-79.

FEISCHMidT M. és NYíRI P. (szerk.) (2006). Nem kívánt gyerekek? Külföldi gyerekek magyar iskolákban. Budapest: MTA Etnikai-nemzeti Kisebbségkutató Intézet, Migrációs és Menekültügyi Kutatóközpont.

Fong, V. (2011). Paradise Redefined. Transnational Chinese Students and the Quest for Flexible Citizenship in the Developed World. California: Stanford University Press.

FÜLÖP, M. (2001). Teachers' perception of the role of competition in their respective countries: Hungary, Japan and USA. Children's Social and Economic Understanding, 4(3), 142159

FÜlÖP M. (szerk.) (2009). A lélek a kultúrák között. A kulturális különbségek pszichológiája. Budapest: Akadémiai Kiadó.

FülÖP M. (2013). A versengés, a gyözelem és a vesztés pszichológiája és kulturális különbségei. Nagydoktori értekezés. Budapest: MTA Doktori Tanács.

FÜLÖP, M., \& BERKICS, M. (2003). Socialisation for coping with competition, winning and losing in two societies: Hungary and the UK. In A. Ross (Ed.), A Europe of Many Cultures (263-273). London: CICE Publication.

FÜlÖP, M., Roland-Levy, C., \& Berkics, M. (2004). Economic competition perceived by French and Hungarian adolescents. In A. Ross (Ed.), The Experience of Citizenship (325331). London: London Metropolitan University.

Güngör, D., Bornstein, M., De Leersnyder, J., Cote, L., Ceulemans, E., \& Mesouita, B. (2012). Acculturation of personality: A three-culture study of Japanese, Japanese Americans, and European Americans. Journal of Cross-Cultural Psychology, 44(5), 701718.

Heine, S. J., \& Lehman, D. R. (2004). Move the body, change the self: Acculturative effects on the self-concept. In M. SChaller, \& C. Crandall (Eds.), Psychological Foundations of Culture (305-331). Mahwah, NJ: Erlbaum.

Kelly, R. M. (1985). The Associative Group Analysis method and evaluation research. Evaluation Review, 9(35), 5-50.

Kemmelmeier, M., \& Cheng, B. Y.-M. (2004). Language and self-construal priming: A replication and extension in a Hong Kong sample. Journal of Cross-cultural Psychology, 35, 705-712.

KovÁcs J. és PÁNTYA J. (2012). A vesztes-szerep mintázatai magyar történelmi események értékelésében. In KovÁcs J. és MÜNNICH Á. (szerk.), Nemzeti emlékezethelyek: attitüdök, reprezentációk, élmények, funkciók, struktúrák (33-56). Debrecen: Debreceni Egyetemi Kiadó.

KOzÉKi B. és HrabAL V. (1983). Az iskoláskorúak teljesítménnyel kapcsolatos motivációjának összehasonlító vizsgálata. Magyar Pedagógia, 2, 121-135. 
LÁsZló J. és FülöP É. (2011). Nemzeti identitás és kollektív áldozati szerep. Pszichológia, 31, 295-315.

LEe, J., \& ZHOU, M. (2014).The success frame and achievement paradox: The costs and consequences for Asian Americans. Race and Social Problems, 6(1), 38-55.

LI, J. (2012). Cultural Foundations of Learning. Cambridge, MA: Cambridge University Press.

Min-Tzu Liao, T. (2007). Chinese Immigrant Children's First Year of Schooling: An Investigation of Chinese Immigrant Parents' Perspectives. Doctoral Dissertation, New Zeland: Unitec Institute of Technology.

Nguyen Luu, L., Fülöp M., Goodwin, R., Göbel, K., Martin Rojo, L., Grad, H. és BERKICS M. (2009). Kínai bevándorló családok gyerekeinek integrációja és szociális támogatottsága. Magyar Pszichológiai Szemle, 64(1), 139-156.

NYíRI P. (2010). Kínai migránsok Magyarországon: Mai tudásunk és aktuális kérdések. In HÁRs Á. és Tóth J. (szerk.), Változó migráció, változó környezet (147-171). Budapest: MTA-ENKI.

SÁNDOR M., Orosz G. és FülÖP M. (2010). A versengés, a győzelem és a vesztés szociális reprezentációja 8-9 éves kisiskolások körében: egy asszociációs vizsgálat tükrében. Pszichológia, 30(3), 175-205.

SzALAY, L. B., \& BRENT, J. E. (1967). The analysis of cultural meanings through free verbal associations. Journal of Social Psychology, 72, 161-187.

Szalay, L. B., \& Bryson, J. A. (1977). Filipinos in the Navy: Service, Interpersonal Relations, and Cultural Adaptation. Washington D.C.: American Institutes for Research.

SzAlay, L. B., \& DeEse, J. (1978). Subjective Meaning and Culture: An Assessment Through World Associations. Hillsdale, NJ: Lawrence Erlbaum Associations.

Szalay, L. B., Strohl, J. B., Fu, L., \& LaO, P. S. (1994). American and Chinese perceptions and belief systems: A people's Republic of China-Taiwanese comparison. New York: Plenum Publishing.

TÓTH I. GY. (szerk.) (2009). TÁRKI európai társadalmi jelentés 2009. Budapest: TÁRKI.

Watkins, D. (2006). The role of competition in today's Hong Kong. The views of Hong Kong Chinese adolescents in comparative perspective. Journal of Social Sciences, 2(3), 85-88.

WATKIns, D. (2007). The nature of competition: The views of students from three regions of the people's Republic of China. In F. SALILI, \& R. HoOSAIN (Eds.), Research in Multicultural Education and International Perspective: Culture, Motivation, and Learning - A Multicultural Perspective (Vol. 6., 217-233). Charlotte, NC: Information Age Publishing.

Zatykó J., Schumann R. és Balogi A. (2013). Harmadik országbeli tanulók iskolai beilleszkedése Budapesten és Szegeden. Szeged: Dél-Alföldi Regionális Társadalomtudományi Kutatási Egyesület. 


\title{
SUBJECTIVE MEANINGS OF COMPETITION, WINNING AND LOSING AMONG HUNGARIAN, CHINESE, AND CHINESE IMMIGRANT STUDENTS LIVING IN HUNGARY
}

\author{
SEBESTYÉN, NÓRA - FÜLÖP, MÁRTA
}

Although there has been a growing number of studies focusing on the cultural embeddedness of competition, winning and losing over the last decade (e.g. FÜLÖP, 2013; WATKINS, 2006), there is no study aimed to investigate the conceptualization of immigrants so far.

The aim of the present study was to reveal the subjective meaning of competition, winning and losing among Hungarian, Chinese and Chinese immigrant students living in Hungary; moreover to investigate the effect of acculturation on the conceptualization.

Altogether, 166 students (52 Chinese, 60 Hungarian and 54 Chinese immigrants) aged 13-15 years participated in the study. The immigrant sample was devided into two subsamples based on the length of residence in order to investigate the influence of cultural exposure in a reliable way. The Associative Group Analysis technique (AGA; SZALAY \& BRENT, 1967) was used to reveal the subjective meanings. The students provided associations to competition, winning and losing (1 minute/stimulus word). The associations were weighted and categorized to identify important meaning components.

The results draw attention to the influence of acculturation on subjective meaning. The study revealed similarity between the meaning structures of the Hungarian and the Chinese immigrant samples in connection with several components. Acculturation had an effect on the meaning components to various extent; the most sensitive component was the emotional aspect. Cultural exposure had the greatest effect on the concept of losing: the subjective meaning of immigrants with greater length of residence is similar to that of the Hungarian sample, while the conceptualization of immigrants with shorter length of residence shows similarity with the Chinese sample.

Key words: $\quad$ AGA, competition, winning, losing, Chinese immigrants, cross-cultural research 